\title{
Effect of Rainfall Variations on Economic Growth in Africa
}

\author{
Olubunmi Olanrewaju \\ Southern University and A \& M College, Public Policy \& Urban Affairs Department, Baton Rouge, Louisiana
}

\begin{abstract}
It is an undeniable fact that African continent is ascribed as an agrarian continent. Majority of the revenue generation and employment options for many of the African countries come from the Agricultural sector. Africa is considered as one of the fastest growing economies in recent times yet, it is vulnerable to climatic risks. These risks have been shown to affect the economic growth of African countries. Using the linear regression model, this study examined the relationship between climate change in form of rainfall variations and economic growth of African countries in past years. The study analyzed secondary datasets of annual rainfall and GDP growth rate of 43 African countries for a period of 25 years between 1991 and 2015. Trends in rainfall variability has impacted on agriculture and hydroelectric power of many African nations, two channels that contribute greatly to the wealth of nations. It is expected that the continent would harness its resources and invest in climate related needs to mitigate against adverse effects caused by rain variation.
\end{abstract}

Keywords: Rainfall, GDP, Economic Growth, Agriculture, Hydroelectricity, and Climate.

DOI: $10.7176 / \mathrm{JESD} / 10-8-09$

Publication date: April $30^{\text {th }} 2019$

\subsection{INTRODUCTION}

Africa's slow and erratic growth performance, particularly when compared to other developing regions, has been identified as the single most important reason behind its lagging position in eradicating poverty (World Bank, 2007). Though different studies consider Africa as one of the fastest growing economies in recent times, World Bank 2018 reports that more than half of the extreme poor live in Sub-Saharan Africa and by 2030, nearly 9 out of 10 extreme poor will be in Sub-Sharan Africa. Of the developing countries, many in Africa are seen as being the most vulnerable to climate variability and change (Slingo et al., 2005). Slingo et al. (2005) further argued that Africa is vulnerable because it is exposed to damaging climate risks. The climate risks are a direct result of the spread of the continent across the Equator. Climate change such as drought, rain variability, temperature fluctuations, and floods has had extreme consequences on the development of African nations. The available evidence from the past clearly shows that the African continent is very likely to face some magnitude of climatic change impacts in the future. Hence, the region needs more serious commitments and actions from communities, governments, regional and international organizations, and other donors than what it is currently getting such that these impacts do not undermine its growth rate.

As part of scholastic evidence of the role of climatic conditions on productivity as well as economic growth, Barrios et al. (2010) used new cross-country panel climatic data to examine how rainfall trends affect the poor growth performance in Sub-Sharan Africa nations compared to other developing nations. Results of their study shows that rainfall is a significant factor in determining the economic growth of African nations. Brown et al. (2010) also did a regression analysis of datasets of rainfall, temperature and per capita GDP to explain the role of rainfall variability in the economic well-being of nations. Their study revealed that poor countries tend to have higher levels of precipitation variability. The future economic growth across the African continent has a high level of dependence on water availability. In turn, water availability is directly reliant on rainfall and its extraction despite any marked interannual variations.

According to World Bank (2008), the two main channels that are likely to be affected by the variation in rainfall in Africa are agriculture and hydroelectric power supply. In the 21st century, agriculture continues to be a fundamental instrument for sustainable development and poverty reduction (World bank, 2008). Agriculture contributes between $20 \%$ and $30 \%$ of GDP as well as $55 \%$ of the total value of African exports (World Bank, 2007). Also, Africa offers a good case study of the impacts of climate changes on electricity generation. In many African countries, hydropower is currently the major source of electricity generation. For example, 70 percent of Kenya's installed capacity of 885 MW comes from hydro, 58 percent of Tanzania's 655 MW, 93 percent of Zambia's 1,786 MW, and 65 percent of Uganda's 580 MW (CIGI, 2009).-Rainfall variability and patterns is assumed to have adverse effects on hydro-power generation.

It has been underscored in development literature that rainfall potentially has a wide array of economic implications anywhere in the developing world (Barrios et al., 2008). Based on available literature, trends in rainfall variability supports that precipitation has been on the decline in Africa since the 1960s, but little is known about how this variation in rainfall patterns has played a peculiar role in African countries' economic growth rates. 
This paper proposes that rainfall variability is correlated with the economic growth and development of African nations, especially the GDP growth rate. Appropriate data for carrying out vulnerability and impact analyses is a key issue, and in many parts of Africa there are serious problems with the existing data collection systems (Thornton et. al, 2008). However, available data on rainfall and per capita GDP of African countries were used to determine the impact of rainfall variability on the growth of African nations. The research adopted a linear regression analysis to examine the relationship between rainfall variation and per capita GDP of 43 African countries. It assessed the effects of rainfall variation on economic growth rate and poverty in Africa so that countries in this region can mitigate against the adverse effects that may arise from these variations.

Rainfall variation was identified as a significant factor to consider in planning for growth, thus, the need for research in Africa. African countries should get more involved in data collection and utilize such to monitor climate change impacts, frame and execute policies to protect natural resources.

\subsection{LITERATURE REVIEW}

Developing countries are generally considered more vulnerable to the effects of climate change than more developed countries and this is largely attributed to a low capacity to adapt in the developing world (Thornton et al., 2006). Africa is the world's second largest and oldest continent as well as the second most populous continent after Asia but countries in Africa are considered as developing countries. Climate is changing all over the world and Africa seems to be exhibiting significant changes in amount of rainfall and patterns, temperature and intensity of other weather extremes. These changes will likely impact the continent because its population is growing, water demand is increasing, and its land and other natural resources are degrading. The economic growth of many countries in Africa depend greatly on water availability and rainfall is a major source of water for these countries. Rainfall affects economic growth in transportation, agriculture, health, energy supply, work motivation and productivity.

Brown and Lall (2006) used fixed and random effects regression with a measure of precipitation variability to estimate impact of climate change on economic growth. The result of their findings was that historical levels of rainfall variability impeded economic progress; hence this factor is very important for future economic growth. Barrios et al. (2010) used the new cross-country panel data to provide evidence of rainfall trends on economic growth in sub-Saharan Africa. They observed that rainfall has impact on the growth of developing countries compared to developed countries. Brown et al. (2010) also found that poor countries were disposed to have higher levels of precipitation variability when they did a regression analysis of datasets of rainfall, temperature and per capita GDP to explain the role of rain variability in the economic well-being of nations. Cabral (2014) also assessed the effects of rainfall changes on growth and poverty using three categories of simulations and concluded that rainfall has a strong effect on agricultural growth, GDP growth and poverty.

Two main channels discussed in this study explain the effect of rainfall variation in Africa. These channels are agriculture and hydroelectric power supply.

\section{Agriculture}

In the 21 st century, agriculture continues to be a fundamental instrument for sustainable development and poverty reduction (World Bank, 2008). The sector's contribution to economic growth and reduction in poverty in developing countries cannot be overlooked. History makes it clear that no country has been able to sustain a rapid transition out of poverty without raising agricultural productivity (Timmer, 2009). A large population of people living in rural areas in developing countries depend on Agriculture for income and employment. Agriculture plays a central role in supporting rural livelihoods and economic growth over most of Africa. People living in both rural and urban areas depend on Agriculture for food at reasonable prices.

The sector is a major contributing factor of GDP in Africa. The large share of agriculture in poorer economies suggests that strong growth in agriculture is critical for promoting overall economic growth. Agriculture provides food, income, and jobs, and hence can be an engine of growth in agriculture-based developing countries and an effective tool to reduce poverty in transforming countries (World Bank, 2007). As noted in the World Development Report 2008, “Agriculture for Development", agriculture and its associated industries are essential to growth and to reducing mass poverty and food insecurity (World Bank, 2008). The Agriculture that provides a livelihood for about three-quarters of Africa's population, is mainly rain-fed (CIGI, 2009). More than half of planted crops in many African countries will not survive without regular rainfall as they depend on it to sustain their crops. 


\section{Hydroelectric Power Supply}

The major source for generating electricity for many African countries is still hydropower. The provision of clean, renewable energy from the construction of hydroelectric dams stimulates economic growth in many of the countries across the continent. The impact of climate change can lead to losses in hydropower potential and electricity generation.

African continent has a long history of rainfall fluctuations of varying lengths and intensities-This pattern alters the timing and magnitude of river flows such that if those financing the hydropower do not harness this resource and provide a responsive environment to improve the hydroelectric generating capacity, it could cause lower water levels, increased runoff, or consequent siltation. This will affect the electricity generating capacity. It will cause a decline in energy production implying lower revenues and poorer returns, as well as an increase in the demand for power, and an increase in electricity costs. Many African countries have suffered a decline in growth rates and living standards as result of low energy production. Therefore, the continent needs to secure water availability by conserving water from rainfall in its hydroelectric dams.

\subsection{METHODOLOGY}

The study uses the quantitative research design. As part of the study design, a multiple linear regression model is used to explore the significance of climate change in the form of rain variability on the economic growth of African countries. Regression variables were developed from global datasets of annual rainfall and GDP growth rate of 43 African countries for a period of 25 years using 1991 as the baseline. The study observed the response of the dependent variable (GDP per capita growth, annual percentage growth rate) to rainfall variation from 1991 to 2015. The annual mean rainfall was calculated using monthly totals from the World Bank Group Climate Change Knowledge Portal while annual percentage growth rate of GDP per capita was retrieved from the World Bank World Development Indicators. GDP per capita growth was used since it's a measure of economic growth at the national level. The study proposes that rainfall is a significant factor to explain a country's economic growth.

\section{Study Hypothesis}

The null hypothesis for this study is that rainfall variation is not significant to a country's economic growth while the alternative hypothesis argues that rainfall variation is an important variable to economic growth.

\section{The Regression Model}

$$
G D P=B_{0}+B_{1} L R A I N+B_{2} L R A I N \_1
$$

Dependent Variable (GDP): GDP per capita growth, annual percentage growth rate Independent Variables: Two independent variables were used to estimate the regression model. The variable LRAIN is the log of rain variation while the Diff (LRAIN_1) is the one-year lagged value of RAIN, an estimate of the impact of previous year's rain variation to this year per capita growth. $\mathrm{B}_{0}, \mathrm{~B}_{1}$ and $\mathrm{B}_{3}$ are the coefficient values (or the slopes) of the independent variables.

\section{Data Analysis}

Statistical techniques applied to the analysis of the study were descriptive and correlation statistics to determine the relationship between rainfall and economic growth. The latter part of the model estimation used regression analysis to predict the values of the dependent variable, while the power of the model and the overall assessment are from the p-values of the regression results.

\subsection{RESULTS AND DISCUSSIONS}

Table 1: Descriptive Summary Statistic of the Model

\begin{tabular}{|c|c|c|c|c|c|}
\hline & $\mathrm{N}$ & Minimum & Maximum & Mean & std. Deviation \\
\hline GDP & 742 & .00406980 & 140.50114736 & $\begin{array}{l}4.336904140 \\
7\end{array}$ & 7.74881916529 \\
\hline LRA IN & 742 & .54 & 9.54 & 4.1012 & 1.00740 \\
\hline DIFF (LRAIN_1) & 741 & -8.43 & 4.84 & -.0003 & 1.42520 \\
\hline $\begin{array}{ll}\text { Valid } & \mathrm{N} \\
\text { (listwise) } & \end{array}$ & 741 & & & & \\
\hline
\end{tabular}

The variable LRAIN is the log of rain variation while the Diff (LRAIN_I) is the one-year lagged value of RAIN, an estimate of the impact of previous year's rain variation to this year per capita growth. 
Table 2: Regression Model Summary

\begin{tabular}{|l|l|l|l|l|}
\hline Model & $R$ & $\begin{array}{l}\text { R } \\
\text { Square }\end{array}$ & $\begin{array}{l}\text { Adjusted } \\
\text { Square }\end{array}$ & $\begin{array}{l}\text { Std. Error of the } \\
\text { Estimate }\end{array}$ \\
\hline 1 & $.831^{a}$ & 0.690 & 0.660 & 7.49194548407 \\
\hline
\end{tabular}

Table 3: Coefficients

\begin{tabular}{|c|l|l|l|l|l|}
\hline Model & \multicolumn{2}{|l|}{$\begin{array}{l}\text { Unstandardized } \\
\text { Coefficients }\end{array}$} & $\begin{array}{l}\text { Standardized } \\
\text { Coefficients }\end{array}$ & t \\
\cline { 2 - 5 } & B & Std. Error & Beta & & Sig. \\
\hline (Constant) & 8.264 & 1.608 & & 5.139 & 0.000 \\
LRAIN & -0.956 & 0.386 & -0.124 & - & 0.014 \\
DIFF (LRAIN_- & 1.822 & .273 & 0.335 & 6.667 & 0.000 \\
\hline
\end{tabular}

Table 1: The descriptive summary statistic of the model variables. The average economic growth rate across the African countries from 1991 to 2015 is 4.3369 while the average log rainfall variable across the African countries from 1991 to 2015 is 4.1012. Meanwhile, the average lag rainfall variable across the African countries from 1991 to 2015 is -0.0003 . On the other hand, the standard deviation value for economic growth rate across the African countries from 1991 to 2015 is 7.7488 while the standard deviation value for the log rainfall variable across the African countries from 1991 to 2015 is 1.0074 . The standard deviation value for the lag rainfall variable across the African countries from 1991 to 2015 is 1.4252 . This implies that there is a higher deviation or variability in the economic growth datasets than the rainfall datasets.

Table 2: As seen from the model summary, the coefficient of determination, R Square of 0.690 shows that rainfall has a variation of $69 \%$ in GDP per capita for African countries.

Table 3: The coefficients and significance of the variables LRAIN and DIFF(LRAIN,1) used in the model.

The significance or p-value of 0.014 for rain variable indicates that there is strong evidence that rainfall is statistically significant at $5 \%$ level while there is very strong evidence that the lagged value of rain, DIFF (LRAIN_1) at 0.000 is statistically significant at $1 \%$ to the economic growth model (GDP). This implies that rainfall has a very strong significant impact on economic growth through productivity (or agricultural produce). That is, in relation to GDP estimation where the productivity from the various sectors of the economy is being utilized to estimate the National income as well as assessing the growth in the economy, it is quite obvious that rainfall is more likely to impact the GDP or the nation's output through agricultural produce which depends on rainfall and weather volatility. The constant value, 8.264 is also statistically significant at $1 \%$ with an associated $\mathrm{p}$-value of 0.000 . Thus, in the absence of rainfall (or when the rainfall value is set to zero), the economic growth (or growth in GDP) will change by 8.264. These results support the alternative hypothesis that rainfall is significant to economic growth, therefore, we reject the null hypothesis.

\subsection{CONCLUSION AND RECOMMENDATION}

It is important to theorize that rainfall is linked to the growth rate of African countries. The analysis of the historical trend between GDP per capita across the 43 African countries relative to rainfall for 25 years shows that these two variables are closely related. Despite the recent years used in this study (1991-2015), it supports previous studies and research that climate in the form of rainfall amount has a very significant impact on economic growth rate. Based on the findings from the analyzed datasets, the study recommends the following: (a) The government of African countries needs to increase resources invested in infrastructure, research and development. (b) Policy framework and consistent policy applications must be put in place to shape the economic success of these countries. (c) A case for higher spending on climate-related needs since investing on this sector has been of lesser priority compared to investing in other budgeted needs (d) Government, development agencies, regional and 
international organizations should harness resources and create programs that are more responsive to the impacts of climate change, which rainfall is of great significance.

\section{REFERENCES}

Barrios, S.; Bertinelli, L.; and Strobl, E. (2010). Trends in Rainfall and Economic Growth in Africa: A Neglected Cause of the African Growth Tragedy. The Review of Economics and Statistics, 92(2), 350-366

Barrios, S.; Ouattara, B.; and Strobl, E. (2008). The impact of climatic change on agricultural production: is it different for Africa? Food Policy, 33(4), 287-298

Brown, C., and Lall, U. (2006). Water and economic development: The role of variability and framework for resilience. Natural Resources Forum, 30: 306-317. Retrieved from https://onlinelibrary.wiley.com/doi/full/10.1111/j.1477-8947.2006.00118.x. Assessed November 17, 2018

Brown, C.; Meeks, R.; Ghile, Y.; and Hunu, K. (2010). An Empirical Analysis of the Effects of Climate Variables on National Level Economic Growth. Policy Research Working Paper: The World Bank Development Economics. Retrieved from http://www.droughtmanagement.info/literature/WB_effect_climate_economic_growth_2010.pdf. Assessed November/December 2018

Cabral, F. (2014). Rainfall and Economic Growth and Poverty: Evidence from Senegal and Burkina Faso. African Growth \& Development Policy Modeling Consortium. Retrieved from http://www.hyalina.com/sites/default/files/AGRODEPWP0008.pdf. Assessed October/November 2018.

Cervantes-Godoy, D., and Dewbre, J. (2010). Economic Importance of Agriculture for Poverty Reduction. OECD Food, Agriculture and Fisheries Working Papers, No. 23, OECD Publishing. doi: $10.1787 / 5 \mathrm{kmmv} 9 \mathrm{~s} 20944$-en

CIGI .(2009). CIGI Special Report: Climate Change in Africa: Adaptation, Mitigation and Governance Challenges. The Centre for International Governance Innovation. Available from https://www.unicef.org/esaro/Climate_Change_in_Africa.pdf. Assessed on November 13, 2018

ClimDev- Africa. (2013). Vulnerability to Climate Change in Africa: Challenges and Recommendations for Africa. Policy Brief 2. Retrieved from https:/www.uneca.org/sites/default/files/PublicationFiles/policy_brief_2_vulnerability_to_climate_cha nge_in_africa_challenges_and_recommendations_for_africa.pdf. Assessed November 15, 2018

DFID-Department for International Development. (2005). DFID's Draft Strategy for Research on Sustainable Agriculture (SRSA) 2006-2016. http://www.dfid.gov.uk/research/srsaconsultation.pdf Accessed November 17, 2018

IPCC. (2007). Climate Change 2007: Impacts, adaptation and vulnerability. Summary for policy makers. http://www.ipcc.ch/pdf/assessment-report/ar4/syr/ar4_syr_spm.pdf Accessed October/November 2018

Kotir, J.H. (2011). Climate change and variability in Sub-Saharan Africa: A review of current and future trends and impacts on agriculture and food security. Environmental Development and Sustainability, 13(3): 587-605

Mishra, A. K., and Singh, V. P. (2011). Drought modeling-A review. Journal of Hydrology, 403(1-2), 157-175.

Ndulu, B., and Chakraborti, L. (2007). Challenges of African growth: Opportunities, constraints, and strategic directions. Washington D.C: World Bank. Retrieved from http://siteresources.worldbank.org/AFRICAEXT/Resources/AFR_Growth_Advance_Edition.pdf

Ravallion, S., and Chen, M. (2004). How have the world's poorest fared since the early 1980s? The World

Sachs, J. D., and Andrew, W. (2001). The Curse of Natural Resources. European Economic Review, 45(4-6): 827-38. Bank Research Observer, 19(2), 141-169.

Slingo, J.M.; Challinor, A.J.; Hiskins, B.J.; and Wheeler, T.R. (2005). Introduction: Food crops in a changing climate. Philosophical Transactions of the Royal Society, Series B 360, 1983-89

Thornton, P.K.; Jones, P.G.; Owiyo, T.M.; Kruska, R.L.; Herrero, M.; Kristjanson, P.; Notenbaert, A.; Bekele, N.; Orindi, V.; Otiende, B.; Ochieng, A.; Bhadwal, S.; Anantram, K.; Nair, S.; Kumar, V.; and Kulkar, U. (2006). Mapping climate vulnerability and poverty in Africa. 200p. Nairobi (Kenya): LRI. Retrieved from https://cgspace.cgiar.org/handle/10568/2307 
Timmer, C. P. (2009). A World without Agriculture? The Historical Paradox of Agricultural Development. American Enterprise Institute. Retrieved from https://www.aei.org/wpcontent/uploads/2011/10/01\%20DPO\%20May\%202009g.pdf on November 26, 2018

Tan-Mullins, M.; Urban, F.; and Mang, G. (2017). Evaluating the Behavior of Chinese Stakeholders Engaged in Large Hydropower Projects in Asia and Africa. The China Quarterly, 230, 464-488.

World Bank. (2007). The International Bank for Reconstruction and Development. The World Bank, Washington, $D C$.

World Development Report .(2008). Agriculture for Development. World Bank, Washington, DC. Retrieved from https://siteresources.worldbank.org/INTWDR2008/Resources/WDR_00_book.pdf 
Journal of Economics and Sustainable Development

ISSN 2222-1700 (Paper) ISSN 2222-2855 (Online)

DOI: $10.7176 / J E S D$

Vol.10, No.8, 2019

APPENDIX

List of African countries used in this report.

\begin{tabular}{|l|l|l|l|}
\hline Algeria & Cote d'Ivoire & Libya & Senegal \\
\hline Angola & Egypt, Arab Rep. & Malawi & Sierra Leone \\
\hline Benin & Equatorial Guinea & Mali & South Africa \\
\hline Botswana & Eritrea & Mauritania & Sudan \\
\hline Burkina Faso & Ethiopia & Mauritius & Tanzania \\
\hline Burundi & Gabon & Morocco & Togo \\
\hline Cameroon & Ghana & Mozambique & Tunisia \\
\hline Central African Republic & Guinea & Namibia & Uganda \\
\hline Chad & Guinea-Bissau & Niger & Zambia \\
\hline Congo, Dem. Rep. & Kenya & Nigeria & Zimbabwe \\
\hline Congo, Rep. & Liberia & Rwanda & \\
\hline
\end{tabular}

